\title{
Between New Education and Idealistic vision: Giuseppe Lombardo Radice and the Arduous Path of L'Educazione Nazionale in Italy (1927-1933).
}

Letterio Todaro, Università di Catania

\begin{abstract}
Opening the issue of Pour l'ère nouvelle (January 1927), Adolphe Ferrière announced that L'Educazione Nazionale, directed by Giuseppe Lombardo Radice, would be the Italian partnership of the educational press officially committed with the New Education Fellowship. The strong relation between the two scholars was based on a shared vision of education as really focused on the release of children's natural energies. The cultural mission of the Italian journal was not an easy one to accomplish, due to the increasingly heavy atmosphere characterizing the Italian public life, signed by the turning of Fascism into an authoritarian Regime. Up to the turning point of the thirties the review often tried to draw attention onto several themes and figures related to the progressive expansion of the New Education. Unfortunately, the involution of Fascism hindered the journal's activity, finally forcing its closure in 1933.
\end{abstract}

Introduction: Giuseppe Lombardo Radice and the impossibility of a pedagogical promise

In a monograph dating back to the beginning of the eighties focused on Giuseppe Lombardo Radice's cultural effort in renewing education, Cives (1983) highlighted the meanings embodied in the expression of a pedagogical creed, both at service of an ideal of "active school» and reluctant to the obligations of the fascist educational model arisen in Italy along the painful period of Mussolini's dictatorship. Particularly, he dedicated some pages to examine the role that Lombardo Radice played in cultivating an educational address connected to the culture of the "active school» by leading the educational journal L'Educazione Nazionale. The Italian journal actually became the voice of a pedagogy responsive to contemporary international movements, acting for changing education according to those innovative and progressive visions variously joining the ideals and the aims of New Education. 
The diligent work done by Cives seems worth being reconsidered and followed up for different reasons, especially for the lately deflecting attention on Lombardo Radice's role in trying to connect the Italian pedagogical culture to an international network. Whereas the interest for Montessori's destiny seems to be timeless and her relevance to the history of New Education still is the subject of an increasing amount of studies, historical examinations of Lombardo Radice's work's relevance seem to be fading. Although Lombardo Radice rejected Montessori's pedagogy - as a kind of unreasonable tightening of children education to a systematic and conventional method, albeit scientifically justified - his insistence on searching for plurality, diversification and variation in the possible declinations of New Education marked the significant opening of a historical crossroad; a crossroad of which an important reference point can be found in the publications of L'Educazione Nazionale.

In this perspective, from the pages of his journal, Lombardo Radice tried to define an Italian route to the ideals of the "active school", based on the unpredictable ways of releasing creativity in education. L'Educazione Nazionale grew out as a severe observer against any attempt to «enclose» educational activities within any arranged definitive scheme. Moreover, in its efforts to attract cultural energies around the concept of «active school» the journal intentionally became a potential amplifier of the educational debates, drawing inspiration from a larger international perspective.

Starting from these premises, the aim of this essay is to broaden Cives' findings and to update the outcomes of his analysis. Special notice will be given to the role that Lombardo Radice played as the organizer of a challenging cultural enterprise as editor of L'Educazione Nazionale. To this end, attention will be especially focused on the period during which the journal officially joined the international network orbiting around the New Education Fellowship (1927-1933).

The capacity to be a talented director of cultural energies and activities was one of the most evident aspects characterizing Lombardo Radice's personality, as pointed out by Adolphe Ferrière, his main counterpart and correspondent in the European context. Likewise, he emphasized the generosity and intrepidity characterizing Lombardo Radice's confidence in the Idealistic thought and cultural trend, which he considered as the main source of the moral energy moving his pedagogical creed (Ferrière, 1926). Indeed, his long training within the Idealistic culture led Lombardo Radice to elaborate a complex pedagogical vision, core to his contribution to the reform of the Italian scholastic system in 1923 and more specifically to the public education primary level, in accordance with the so-called ideal of the "serene» school. Besides, according to Ferrière, the relationship between the concepts of «serene» and "active» school clearly outlined the aesthetic tendency of Lombardo Radice's original elaboration of Idealism in education, which largely inspired the scholastic reform he promoted (Chiosso, 2019, pp. 122-153). 
The evolution of L'Educazione Nazionale while it was related to the New Education Fellowship can suggest a new perspective on the capacity of that kind of Idealism to hold on an educational project able to polarize a large amount of supporting forces. Actually, the challenge launched by Lombardo Radice seemed to have fallen quite out of time, one hard to maintain, eroded by the political and cultural lines imposed by the fascist regime on the public life as well as by the progressive dismissal of the Idealistic address, as a convenient paradigm for keeping up the ideological principles promoted by fascism as «system of culture». The hypothesis leading our historical reconstruction is based on the insight provided by this understanding of an unsynchronized timing of Lombardo Radice's challenge, due to which it was doomed to fail.

For this historical reconstruction, the publications of L'Educazione Nazionale in the late twenties up to the final closing of its editorial life, ordered by the fascist authorities in 1933, will be examined. Therefore, the methodological approach used in this paper is structured around a chronological investigation. It is aimed at deducing contents, concerns, connections and goals inspiring Lombardo Radice's initiative, despite the adverse conditions it had to face, especially in front of the progressive absorption of the Italian cultural life into the structures of a totalitarian State.

\section{The hard task of an educational journal in a collapsing liberal system: L'Educazione Nazionale and its troubled mission within the Italian context}

The process of internationalization of the New Education Fellowship as a growing movement promoting a transnational reforming perspective on education found one of its most fruitful vehicles in the attempt to enlarge joint editorial activities through a network of concurrent journals (Gutierrez, 2011). The publication of numerous educational reviews in different cultural areas and national contexts substantially contributed to support the dissemination of new pedagogical addresses. This effort originated from the need to face specific cultural and political conditions mobilizing new energies for the New Education cultural mission (Gutierrez, 2009, p. 9).

The Italian case deserves special attention because of the peculiar political and cultural context characterizing the early decades of the Twentieth Century, as the process of transformation of the fascist government into a totalitarian regime precluded any liberal debate on education. This made the New Education Fellowship's attempts to stabilize new educational perspectives particularly hard. The restrictions over cultural life, affecting every context of public life, heavily limited free speech on education, hindering all pedagogical expressions explicitly aimed at contributing to internationally shared goals and perspectives on education. 
The high pressure on the educational field became evident in the late twenties, when all the main aspects of public life were totally absorbed in the totalitarian frame (De Felice, 1968). The arduous path of the Italian educational journal L'Educazione Nazionale, directed by Giuseppe Lombardo Radice, in these years can be considered as a meaningful example of how a system of restraints limited freedom of expression, opinion and cultural cooperation in the Italian context. The forced silence the review was in the end compelled to was the ineluctable outcome for having embraced a vision of education which was incompatible with the "fascist revolution» and basically grounded in the profession of liberal thought. The increasing marginalization of Lombardo Radice's journal and the definitive stop to its publications marked the unfortunate destiny of an important pedagogical laboratory whose leading aim had consisted in the courageous attempt to obtain clear recognition of the progressive push brought about by the New Education wave, though necessarily passed through the filter of an idealistic concept.

The beginning of 1927 can be highlighted as the starting point of this awkward path, marking the official commitment of L'Educazione Nazionale to the larger front of the international press connected to the New Education Fellowship. The announcement made by Adolphe Ferrière (1927a, p. 2) from the pages of Pour L'Ere Nouvelle expressly defined the concurrent reasons at work to tie such an alliance and clearly outlined the double movement in act: the Italian journal was joining the cultural struggle arising on the international scene, and at the same time the new Education Fellowship would recognize the value of the Italian partnership in a common cause.

The Italian partnership was surely considered as particularly valuable for the distinguished figure of the review's director, Giuseppe Lombardo Radice (Chiosso, 1997). He had been the main character in the primary school reform passed with Gentile's Act in 1923 as well as the author of the new syllabuses for elementary instruction (Catarsi, 1990). The review was perceived as a meaningful pedagogical initiative aiming at revitalizing school life through an idealized and quite romantic vision of childhood, largely ascribable to the principles of the New Education (De Fort, 1996; Ostenc, 1981).

The enthusiasm showed by Ferrière in enrolling L'Educazione Nazionale among the journals supporting the New Education Fellowship was therefore due to the fact that it could be considered as a trustworthy organ which had contributed to the elevation of the ends of education even before Pour l'Ere nouvelle.

The ideological convergence between Ferrière and Lombardo Radice was basically grounded in their shared faith in the deepest sense of education seen as the realm of total liberation of all the energies characterizing childhood. Such a vision of education was manifest in the pronouncement of the first principle affirmed at Calais, in the founding manifesto of the New Education Fellowship:

The essential aim of any education is to prepare the child to seek and realize the supremacy of the spirit in his own life. Whatever other view the educator 
may take, education should aim at maintaining and increasing the spiritual energy in the child. (Brehony, 2004, p.753).

Short before an issue of Pour L'Ére Nouvelle had almost entirely been dedicated to illustrate interesting cases of penetration of the New Education's culture in Italy and their positive pedagogical repercussions. The beginning of 1927 seemed therefore to represent a favourable conjuncture for the mutual relationship between the two journals to be reaffirmed.

In an article entitled L'École Active dans la reforme du Ministre Gentile et dans les classes expérimentales dites de différenciation didactique (Lombardo Radice, 1926a), later published in Italian in his review (Lombardo Radice, 1927a), Lombardo Radice clearly expounds his point of view on the crucial question of the relationship between Gentile's school reform and the principles of the New Education. Enumerating the many reasons for Gentile's scholastic reform to be intended as a direct emanation of the New Education's cultural groundings especially at the primary education level - and thus obstinately defending its original features, he was trying to preserve the continuity of that educational project, in spite of the alterations that the political government was progressively determining (Dogliani, 2014). Lombardo Radice argued on these ideas in detail, carefully maintaining his discourse on a strictly pedagogical level of reasoning and carefully avoiding any direct reference to the current political context.

The attempt to preserve the pedagogical domain from the infiltration of any other spurious discourse put forward the same demand issued by the journal L'Educazione Nazionale when it publicly came out as a press service directed to encourage the recognition of the New Education principles. The clear attitude of stressing the pertinence of a discourse on education and school as a technical issue exclusively concerning educators and specialists, reflected Lombardo Radice's problematic and quite illusory position in front of the mighty transformation in act in the Italian cultural panorama, and interpreted at the same time the hard mission undertaken by L'Educazione Nazionale, whose stated intention and cultural program was to enter the pedagogical debate without any external interference. Despite the objective difficulties, such an enterprise still seemed to be potentially practicable at the turning of 1927 and the review was able to proceed with its program and cultural aims.

\section{L'Educazione Nazionale and the New Education Fellowship: the faith in a pedagogical alliance in a spirit of autonomy}

A glance at the publications of L'Educazione Nazionale during 1927 clearly shows a remarkable attempt to launch and support a series of initiatives which reflected a dynamic synergy with the Genevan frontline of the New Education Fellowship: a circumstance which gave a peculiar stamp to the Italian journal, one inherently 
descending from the basic convergence and compatibility between Lombardo Radice and Ferrière's pedagogical views. This was observable in the warm participation that the editorial board of L'Educazione Nazionale showed at the beginning of the year advertising the upcoming New Education Fellowship Conference to be held in Locarno in the following August (Lombardo Radice, 1927b).

The event was announced as a central appointment for all the educators involved in a shared agenda. Lombardo Radice emphasized the value of its location in Locarno as an intentional connection between the event and the Italian culture, meant to encourage the participation of Italian educators. $\mathrm{He}$ also underlined the spirit of collaboration that the Conference was to interpret, gathering educators from various nations, widely promoting multilateral contacts and yet respecting and enhancing the peculiarity of every national contribution, in a larger spirit of mutual comprehension.

Unfortunately, the course of events would get to a different conclusion, quite far from the one Lombardo Radice had prefigured. The borderline position occupied by the Italian delegates in the international context due to the current national situation contributed to the failing Italian representation at the conference. Despite Ferrière's diplomatic endevours to mitigate tensions, the Italian participation would prove to be insignificant and Lombardo Radice decided to avoid further embarrassment remaining in Italy and sending his written contribution to be later collected in the Conference papers (Lombardo Radice, 1927c, 1927d). Nonetheless, L'Educazione Nazionale preserved its allegiance to the Conference issues, presenting to the readers both the text of Lombardo Radice's presentation and a more general report on the debate held in the different sessions of the conference (Lombardo Radice, 1927e).

Meanwhile, another significant initiative had been announced in the February issue of L'Educazione Nazionale, similarly promoted in close correspondence of purposes with the Genevan frontline and spreading from a shared intention to celebrate the centenary of Pestalozzi's death. The anniversary was conceived as a considerable opportunity to draw attention on an ideal of active school, currently interpreted to the largest extent by the New Education spirit.

The most appropriate way to give resonance to the event was the publication of a series of four paperbacks - Quaderni Pestalozziani - edited as independent supplements to the journal though in close continuity with the editorial plan. Presenting the publication of the first volume, entitled Il nostro Pestalozzi (1927f), Lombardo Radice, who was in charge as director of L'Educazione Nazionale and supervisor of the special editorial plan devoted to Pestalozzi's figure, highlighted the meaning of that cultural operation: not a mere occasion for rhetorical and academic discourses, but an opportunity to carry on a wider program aimed at renewing education in the name of a truely living and «serene» school (Lombardo Radice, 1927g).

The original contribution given by Lombardo Radice to the book focused the question underlying the ideal continuity which linked Pestalozzi's educa- 
tional model to the current «active school» insights: a correspondence grounded in the acknowledgment of education as a continuous creation resulting from the expansion of one's own inner personality, constantly stimulated by the productive involvement in a variety of activities and conveniently encouraged by the teachers (Lombardo Radice, 1927f).

The choice to have supplementary materials published apart from the journal issues, represented a strategic system to foster the enlargement of the specific perspectives promoted in consonance with the New Education Fellowship, enriching the public debate on education beyond the collection edited for the Pestalozzi celebrations.

In this sense, the publication of special paperbacks aimed at giving prominence to innovative experiences in act in the Italian context, highlighting original educational practices and innovating methods in children's early education and conveniently presenting them as belonging to the «active school» spirit. In so far, Lombardo Radice focused his attention on the experimental kindergarten set by Rina Nigrisoli, illustrating her original way to arrange the children's observations of the environment in the special report I piccoli Fabre di Portomaggiore (1926b); while, at the same time, Maurilio Salvoni disclosed the innovative views that led him to model new learning practices on the concept of «spontaneous activity» at the "Carducci» Institute in Como, in the special dossier Un ventennio di scuola attiva (1927).

Another relevant signal of the convergence between the Italian pedagogical journal and the Genevan area of the New Education Fellowship across 1927 was the contribution given by Adolphe Ferrière to the review issues. Particularly, he participated with a passionate tribute to the memory of Virginia Povegliano Lorenzetto, a brilliant Roman young teacher who had been testing facilitating methods for various types of children behindered in learning and who had unfortunately passed away at the age of 36 . In the contribution, she was remembered as a pioneer of the active school in Italy and also indicated as one of the most valuable contact persons Ferrière used to count on in the Italian area (Ferrière, 1927b).

Acting on these different levels, L'Educazione Nazionale not only attempted to strengthen the connections with the large area of initiatives related to the contemporary expansion of the New Education networks (Stewart, 1968), but also tried to mark a distinctive Italian way to fall in line with that widening typical address on education. In this perspective one can also read Lombardo Radice's fine analysis of the Agazzi sisters' methods in children education as the most reliable contribution of the Italian educational culture to the wide contemporary development of the active school.

From the pages of L'Educazione Nazionale, Lombardo Radice invited to recognize in the Agazzi's methods adopted in the Mompiano kindergartens the most authentic Italian contribution to the international educational scene, thus providing formal approval to an experience displaying the distinguishing characters of the national culture applied to the education of children (Lombardo Radice, 1927h, 1927i). 
The laborious work developed by Lombardo Radice to validate the Agazzi methods counterbalanced his persistent critical work to reject Montessori's ones (Lombardo Radice, 1926c) thus furtherly marking a crucial turn towards a new direction in the Italian pedagogy. Lombardo Radice's work was primarily noteworthy for positioning L'Educazione Nazionale in a peculiar area of the reforming educational cultures within the wider progressive framework, definitely marking the journal's address as strongly tangled with an Idealistic understanding of education and children's lives. In addition, it paved a distinct path for the future growth of an Italian official pedagogical line, beyond the incidental swerve of the Fascist era. Such Italian line identified with a conception of children's education which completely corresponded to the recognition of a national character, aiming at the realization of an aesthetic, poetic and religious insight in children's lives and rejecting the idea of a controlled and methodologically oriented scientific discernment.

Lombardo Radice's idea of a strong opposition between the two cultural options of the Agazzi and Montessori methods heavily contributed to cause an ideal split between a romantic feeling and a scientific conception of children's lives. In so far, the choice in favor of the Agazzi system of early education would mean to assign a basic preference to freedom against mechanism. In his view, the Agazzi sisters' method was to be implemented in order to promote creativity, spontaneity, naturalness, whereas Montessori's instructions represented imposition of limits, formality, stereotyping customs (Lombardo Radice, 1928a).

The strong effort put by Lombardo Radice in finding an ideal symmetry between the «spirit» leading the children education and the distinctive characters of the national identity (Moretti, 2011), which can be read as a further result of his idealistic understanding, was in assonance with a simultaneous consciousness of education as a universalistic concept. This position never conducted him to undervalue international cooperation and the transnational exchange nor to dismiss the accreditability of educational assignments to a wide human horizon largely overpassing the national borders.

Despite the apparent limits related to its title, the cultural address promoted by L'Educazione Nazionale never led the review to curb its cultural horizons to a delimited area of national interests; and even less did the nominal reference to the national area give to the journal a character assimilable in any way to the fascist involution of national life towards autarky (Gentile, 2006).

On the contrary, the views inspiring the journal clearly showed full attention to the international panorama, making of its interest in innovation and experimentation in education a distinguishing mark. The journal's innovation-oriented attitude would actually be one of the main aspects eventually destined to arouse suspicion among the government authorities and have the review finally put under control.

The studies published during 1927 prove the journal's increasing interest towards the new educational addresses debated abroad. A detailed essay was 
dedicated to the educational model adopted by the praiseworthy French private institution of L'École des Roches (Ferrari, 1927). A series of studies on Dewey's pedagogy followed, among which the first analysis by Matilde Cimmaruta (1927) praised the concrete investment on children's interests while setting up the educational activities as the most significant aspect of Dewey's insights.

Doubtless, Dewey's interpretation promoted by the Italian review appeared significantly influenced by the disturbing idealistic elements deeply affecting Lombardo Radice's vision and his scholarship (Bellatalla, 1999). Nonetheless, these latter still do not impede the acknowledgment of some typical characters related to Dewey's most genuine insights. In so far, the journal identified the core reason of Dewey's pedagogy in the idea that learning can happen only «by doing» and through an active participation to social life. The stress of Dewey's pedagogy on personal activity and individual contribution to the development of social life came to light again in Rossi Longhi's comment to Democracy and Education (1927), which energically fostered the appreciation of the American progressive culture in Italy (Arcara, 1927). On the whole, 1927 proved to be a fruitful year for the Italian journal, devoting a great deal of effort to the diffusion of a liberal and modern conception of education.

Nevertheless Lombardo Radice did not fail to point out some worrying aspects for the incoming future. Looking back to the considerable amount of work developed, he could not help noticing the discomforting decrease in the journal's subscriptions despite the appreciable quantity and quality of papers offered to the readers. In his evaluation, the journal's editorial results did not reflect the good «moral» outcomes achieved. Looking at the transition to the following year, and implicitly referring his words to the more general cultural and political situation, the director expressed his concern about the new year, wishing the readers a good 1928 but prudently avoiding to compromise the journal's future with big promises (Lombardo Radice, 1928b).

\section{"L'Educazione Nazionale" and the troublesome late years to the journal's forced closure.}

An earnest expression of Lombardo Radice's discomfort about the troublesome atmosphere casting a shadow over the editorial activity as well as a signal of his felt sense of pressure could be found in the letter he sent to Ferrière dated October 10 1927 (cited in Picco, 1968, pp. 273-274). In the letter, a feeling of growing helplessness is quite clearly perceiveable, as Lombardo Radice sincerely acknowledged the impossibility to make more than he was just doing for the New Education cause.

Moreover, the easy familiarity with Ferrière allowed him to insist on the reasons for them to stand for a close collaboration, whose deepest inner meaning was to consist in a real cooperation free of any cultural dependency or subordi- 
nation. For this reason, Lombardo Radice ceaselessly marked the full adhesion of his journal to the cultural outlines marked to the New Education Fellowship, yet at the same time claiming full autonomy of judgement in the general convergence between the journal contents and the New Education principles.

Despite the growingly close control on cultural life brought about by the shift of Fascism into a totalitarian system (Gentile, 2001), the journal tried to keep holding to a coherent vision and devoting full attention to the international debate on education. The consequences of the adverse conditions were reflected in the journal's struggle to keep its standards as high as the ones previously performed.

Nevertheless, the journal's effort to keep an eye on the main changes in act in the international panorama could be seen in several contexts until the thirties. For instance, a significant amount of editorial energies was dedicated to a series of studies on the Dalton Laboratory Plan (Mungo, 1928, 1929a, 1929b). During 1929, a new series of articles came out to highlight Ferrière's deep devotion to the expansion of the active school (Lombardo Radice, 1929), with a dedicated space for the publication of excerpts from his writings, as a special tribute to his fiftieth birthday (Ferrière, 1929).

The journal's allegiance to the spirit of New Education was furtherly kept alive by the editorial board's effort devoted to the compilation of detailed bibliographical references, as well as to the publication of brief summaries, essays, articles, book reviews and news about the most interesting events or latest publications in the field of New Education.

Among the articles appeared in 1930, Lombardo Radice's article on the status of the pedagogical problem in John Dewey's work deserves a special mention. Here again, while the understanding of Dewey's conceptions was tinged by Lombardo Radice's idealistic assumptions, the focus on the moral dimensions resulting from Dewey's beliefs on education still allowed him to point out some remarkable issues related to the special context in which he was working. Emphasizing the importance placed by Dewey on the individual versus society, Lombardo Radice confirmed the value of education as an inner drive to raise personal awareness, encouraging everyone to act as active subjects and shaping the social relations in which one is involved. Education, on the other hand, was never conceived as a force pressing and pushing personal consciousness or even less encouraging consciousness to be driven by external automatisms and premodelled patterns (Lombardo Radice, 1930a).

Along the troubled turn to the thirties, while the general tones of the journal seemed to shift towards a detached atmosphere and a mainly theoretical dimension of debates, the last references to the New Education progressive ideas were mentions of some interesting characters or experimental schools, such as Ellen Key (Ravà Pergola, 1931), Ovide Decroly (La Torraca, 1931), the Lugano schools (De Rossi, 1931; Matano, 1931), and the Italian case represented by Giuseppina Pizzigoni and «La Rinnovata» school (Lombardo Radice, 1930b). 
"La Rinnovata» was pointed out as a highly valuable realization of a reformed system of children education in a pioneering spirit of creativity (Rossi Cassottana, 2014).

The weakening of the journal's energies corresponded to the increasing marginalization of Lombardo Radice within the national cultural life (Colaci, 2000): the review was gradually perceived as the expression of an outsider's voice within the cultural Italian scene, and its director progressively fell into fatal isolation, relegated far from the mainstream dominating the cultural scene.

The ideological divergence finally burst into an official act of injunction from the Italian authorities: the disclosure of educational theories and cultures from other nations, and the obstinate silence on what the Fascist government was currently praising as the highest revolution lead by the Regime in schooling and education was the main accusation charged onto the editorial board and officially transmitted to Lombardo Radice on April $8^{\text {th }} 1933$. It concretely corresponded to an imposed definitive stop to the journal's publications, a measure which actually deprived the Italian educational culture of one of the last «independent» voices claiming in the desert of an acquiescent and conforming public life (Chiosso, 2013).

\section{Bibliography}

Arcara, G. (1927). «New Schools in the Old World». Nuove scuole nel vecchio mondo. L’Educazione Nazionale, IX(maggio), 284-298.

Bellatalla, L. (1999). John Dewey e la cultura italiana del Novecento. Pisa, Italia: Ets.

Brehony, K. J. (2004). A new education for a new era: the contribution of the conferences of the New Education Fellowship to the disciplinary field of education 1921-1938. Paedagogica Historica, 40(5-6), 733-755.

Catarsi, E. (1990). Storia dei programmi della scuola elementare (1860-1985). Firenze, Italia: La Nuova Italia.

Chiosso, G. (1997). L'Educazione Nazionale. In G. Chiosso (Éd.), La stampa pedagogica e scolastica (1820-1943) (pp. 284-287). Brescia, Italia: La Scuola.

Chiosso, G. (2013). Libri di scuola e mercato editoriale. Dal primo Ottocento alla Riforma Gentile. Milano, Italia: Franco Angeli.

Chiosso, G. (2019). L’educazione degli italiani. Laicità, progresso e nazione nel primo Novecento. Bologna, Italia: Il Mulino.

Cimmaruta, M. (1927). La pedagogia di John Dewey. Scuole di domani. L'Educazione Nazionale, IX(luglio), 446-457.

Cives, G. (1983). Attivismo e antifascismo in Giuseppe Lombardo Radice. Firenze, Italia: La Nuova Italia.

Colaci, A. M. (2000). Gli anni della riforma. Giuseppe Lombardo Radice e "L'Educazione Nazionale». Lecce, Italia: Pensa editore.

De Felice, R. (1968). Mussolini il fascista. L'organizzazione dello Stato totalitario (1925-1929). Torino, Italia: Einaudi.

De Fort, E. (1996). La scuola elementare dall'Unità alla caduta del fascismo. Bologna, Italia: Il Mulino

De Rossi, O. (1931). Documenti sulla scuola serena. A Lugano: i bimbi e gli animali. L'Educazione Nazionale, XIII(gennaio), 45-54.

Dogliani, P. (2014). Il fascismo degli italiani. Una storia sociale. Torino, Italia: Utet. 
Ferrari, V. (1927). La scuola des Roches. L'Educazione Nazionale, IX(giugno), 384-398.

Ferrière, A. (1926). Une visite aux pionniers de l'École Active en Italie. Pour l'Ére Nouvelle, 5(23), 150-156.

Ferrière, A. (1927a). Éditorial. Pour l'Ére Nouvelle, 6(24), 1-2.

Ferrière, A. (1927b). Virginia Povegliano Lorenzetto. L'Educazione Nazionale, IX(gennaio), 4-14.

Ferrière, A. (1929). Una visita ai pionieri della 'scuola serena' in Italia. L'Educazione Nazionale, XI(giugno), 280-288.

Gentile, E. (2001). La via italiana al totalitarismo. Il partito e lo Stato nel regime fascista. Roma, Italia: Carocci.

Gentile, E. (2006). La grande Italia. Il mito della nazione nel XX secolo. Roma-Bari, Italia: Laterza.

Gutierrez, L. (2009). La Ligue Internationale pour l'Éducation Nouvelle. Contribution à l'histoire d'un mouvement international de réforme de l'enseignement (1921-1939). Spirale - Revue de Recherches en Education, 5, 29-42.

Gutierrez, L. (2011). Les premières années du Groupe Français d'Éducation Nouvelle (19211940). Recherches \& Éducations, 4, 27-39.

La Torraca, M. (1931). Il metodo Decroly. L'Educazione Nazionale, XIII(agosto-settembre), 424-449.

Lombardo Radice, G. (1926a). L'École Active dans la reforme du Ministre Gentile et dans les classes expérimentales dites de différenciation didactique. Pour l'Ère Nouvelle, 5(23), 176-184.

Lombardo Radice, G. (1926b). I piccoli Fabre di Portomaggiore. Roma, Italia: Associazione per il Mezzogiorno.

Lombardo Radice, G. (1926c). La nuova edizione del «Metodo della pedagogia scientifica» di Maria Montessori. L'Educazione Nazionale, VIII(luglio), 33-50.

Lombardo Radice, G. (1927a). La scuola attiva nella riforma Gentile e le classi di differenziazione didattica. L'Educazione Nazionale, IX(gennaio), 20-32.

Lombardo Radice, G. (1927b). Il Congresso dell' «Educazione Nuova» a Locarno, 3-15 agosto 1927. L'Educazione Nazionale, IX(gennaio), 1-3.

Lombardo Radice, G. (1927c). Le problème de la liberté en éducation: la liberté véritable et la fausse liberté en éducation. Pour l'Ére Nouvelle, 6(31), 181-184.

Lombardo Radice, G. (1927d). A proposito del Congresso Pedagogico di Locarno. L'Educazione Nazionale, IX(maggio), 275.

Lombardo Radice, G. (1927e). Vera e falsa libertà nell'educazione. L'Educazione Nazionale, IX(maggio), 289-293.

Lombardo Radice, G. (1927f). Il nostro Pestalozzi. In G. Lombardo Radice (Éd.), Il nostro Pestalozzi (pp. 81-106). Roma, Italia: L'Educazione Nazionale.

Lombardo Radice, G. (1927g). Le onoranze italiane a G. E. Pestalozzi. In G. Lombardo Radice (Éd.), Il nostro Pestalozzi (pp. 3-6). Roma, Italia: L'Educazione Nazionale.

Lombardo Radice, G. (1927h). Il metodo italiano. Vita dei fanciulli e metodo didattico dell'asilo di Mompiano (1898-1926). L'Educazione Nazionale, IX(marzo), 145-153.

Lombardo Radice, G. (1927i). Il metodo italiano nell'educazione dell'infanzia. Il materiale Agazzi. L'Educazione Nazionale, IX(aprile), 207-225.

Lombardo Radice, G. (1928a). Agazzi e Montessori. L'Educazione Nazionale, X(giugno), 313-321.

Lombardo Radice, G. (1928b). Anno Nuovo. Il nostro bilancio del 1927, e il nostro augurio per il 1928. L'Educazione Nazionale, X(gennaio), 1-4.

Lombardo Radice, G. (1929). Le benemerenze di Adolfo Ferrière per la scuola attiva, L'Educazione Nazionale, XI(settembre-ottobre), 413-422.

Lombardo Radice, G. (1930a). Limpostazione del problema pedagogico in John Dewey. L'Educazione Nazionale, XII(giugno-luglio), 281-287. 
Lombardo Radice, G. (1930b). Testimonianze per Giuseppina Pizzigoni. L'Educazione Nazionale, XII(febbraio), 97-114; (marzo), 121-151.

Matano, B. (1931). Documenti sulla scuola serena. Il tema libero in quinta classe delle scuole di Lugano. L'Educazione Nazionale, XIII(febbraio), 103-107.

Moretti, E. (2011). Il Metodo: Maria Montessori and Early Childhood Education in Italy (1909-1926). Cromohs, 16, 1-18. Retrieved from http://www.fupress.net/index.php/ cromohs/article/view/13674/12739.

Mungo, C. (1928). Il «Dalton Laboratory Plan». L'Educazione Nazionale, X(dicembre), 587-598.

Mungo, C. (1929a). Il «Dalton Laboratory Plan». Esposizione del metodo. L'Educazione Nazionale, XI(gennaio), 12-15.

Mungo, C. (1929b). Il Dalton Laboratory Plan nel suo ambiente storico. L'Educazione Nazionale, XI(marzo), 129-138.

Ostenc, M. (1981). La scuola italiana durante il fascismo. Roma-Bari, Italia: Laterza.

Picco, I. (1968). Nove lettere inedite di Giuseppe Lombardo Radice. I problemi della pedagogia, $X I V(3), 261-275$.

Ravà Pergola, B. (1931). In memoria di Ellen Key. L'Educazione Nazionale, XIII(giugnoluglio), 291-299.

Rossi Cassottana, O. (2014). L'attivismo e la figura di Giuseppina Pizzigoni. Riletture critiche. Rivista Formazione Lavoro Persona, IV(10), 1-27.

Rossi Longhi, M. L. (1927). La pedagogia di John Dewey. Appunti su «Democracy and Education". L'Educazione Nazionale, IX(ottobre), 582-589.

Salvoni, M. (1927). Un ventennio di scuola attiva. Roma, Italia: Associazione per il Mezzogiorno.

Stewart, W. A. C. (1968). The International Movement in Progressive Education. In W. A. C. Stewart (Éd.), The Educational Innovators. Volume II: Progressive Schools 1881-1967 (pp. 217-242). London, England: Macmillan \& Co. Ltd.

Keywords: New Education Fellowship, active school, Adolphe Ferrière, Giuseppe Lombardo Radice, fascism.

\section{Die schwierige Aufgabe einer Zeitschrift für Erziehung in einem zusammenbrechenden liberalen System: L'Educazione Nazionale und ihre veränderte Mission in Italien's Kontext}

\section{Zusammenfassung}

Adolphe Ferrière eröffnete im Jahr 1927 die Januarausgabe der Zeitschrift Pour l'Ére Nouvelle mit der Ankündigung einer wichtigen Neuerung: Von Beginn des neuen Jahres an würde die von Giuseppe Lombardo Radice geleitete Zeitschrift L'Educazione Nazionale der italienische Partner sein, der offiziell die New Education Fellowship vertrete. Die starke Beziehung zwischen den beiden Wissenschaftlern basierte auf einer gemeinsamen Vision von Bildung, die sich auf die Entfaltung der natürlichen Energien der Kinder konzentrierte. Die kulturelle Mission der italienischen Zeitschrift war nicht einfach zu erfüllen, da die Atmosphäre, die das damalige italienische Leben prägte von der fortschreitenden Umwandlung des Faschismus in ein autoritäres Regime geprägt war. Bis hin zur 
Wende in den dreissiger Jahren versuchte die Zeitschrift oft, die Aufmerksamkeit der Leser/innen aufThemen und Schlüsselfiguren innerhalb der expandierenden Ansätze der Reformpädagogik zu lenken. Leider behinderte die Ideologisierung von Seiten des Faschismus die Tätigkeit der Zeitschrift und zwang sie schliesslich 1933 zur Schliessung.

Schlagworte: Reformpädagogik, Schulreform, Adolphe Ferrière, Giuseppe Lombardo Radice, Faschismus

\section{Une imbrication originale entre l'Éducation Nouvelle et les orientations idéalistes: Giuseppe Lombardo Radice et le parcours difficile du journal L'Educazione Nazionale en Italie (1927-1933)}

\section{Résumé}

En inaugurant le numéro de janvier de l'année 1927 de Pour l'Ère Nouvelle, Adolphe Ferrière annonçait une importante nouveauté: la revue L'Educazione Nazionale, dirigée par Giuseppe Lombardo Radice, représenterait en Italie le mouvement pédagogique international organisé autour de la Ligue Internationale pour l'Éducation Nouvelle. L'annonce réaffirmait la forte sympathie existant entre les deux chercheurs, basée sur le partage d'un engagement généreux consacré à l'éducation, destinée à libérer les énergies vivantes de l'enfance. La tâche entreprise par la revue italienne fut cependant difficile à maintenir en raison de la transformation progressive de l'Italie fasciste en un État totalitaire. Jusqu'au début des années 1930, son journal tenta de maintenir l'objectif fixé pour la modernisation pédagogique. Cette direction devait conduire à une incompatibilité avec les directives imposées par les autorités du fascisme et, en 1933, le journal fut fermé par ordre du gouvernement.

Mots-clés: Éducation nouvelle, réforme pédagogique, Adolphe Ferrière, Giuseppe Lombardo Radice, Italie fasciste 


\section{Un originale intreccio fra Educazione Nuova e orientamenti idealistici: Giuseppe Lombardo Radice e il difficile percorso del giornale L'Educazione Nazionale in Italia (1927-1933).}

\section{Riassunto}

Aprendo il numero di gennaio del 1927 di Pour l'Ère Nouvelle, Adolphe Fèrriere annunciava un'importante novità: a partire dal nuovo anno, la rivista che avrebbe rappresentato in Italia il movimento pedagogico organizzato intorno alla Lega Internazionale per l'Educazione Nuova, sarebbe stata L'Educazione Nazionale, diretta da Giuseppe Lombardo Radice. L'annuncio ribadiva la forte simpatia esistente tra i due studiosi, basata sulla condivisione di un generoso impegno a favore dell'educazione, intesa come liberazione delle energie vive dell'infanzia. Il compito assunto dalla rivista italiana si sarebbe rivelato assai arduo da mantenere, poiché nel frattempo, l'atmosfera culturale egemone nel Paese volgeva verso direzioni contrarie, in ragione della progressiva trasformazione dell'Italia fascista in uno Stato totalitario.

Parole chiave: Educazione Nuova, attivismo, Adolphe Ferrière, Giuseppe Lombardo Radice, fascismo

Letterio Todaro is Associate Professor in History of Education at the University of Catania (Department of Educational Sciences). His research field is mainly focused on the history of education in Italy between the Nineteenth and the Twentieth Century. In this regard, he has published several articles on the penetration of the progressive ideas and the innovative cultural addresses of the New Education into the national context, exploring the educational publishing and specialized press and highlighting the main characters concerned with reforming education and promoting the ideals of 'active school'.

Università degli Studi di Catania, Via Biblioteca, 4, piano terra, stanza XI, I-95131 Catania,

E-Mail: 1.todaro@unict.it 